\title{
The Effect of Zam-zam Water to the Lipid Profile (HDL \& LDL) at White Mouse (Rattus novergicus)
}

\author{
Pengaruh Pemberian Air Zam-zam terhadap Profil Lipid (HDL \& LDL) pada Tikus Putih (Rattus \\ novergicus) \\ Yhang Lidi Tama ${ }^{1}$, Sagiran ${ }^{1 *}$ \\ ${ }^{1}$ Medical Education Study Program, Faculty of Medicine and Health Sciences, Universitas Muhammadiyah \\ Yogyakarta
}

DATA OF ARTICLE:

Received: 9 Feb 2019

Reviewed: 20 Mar 2019

Revised: 17 Jun 2019

Accepted: 25 Jun 2019

*CORRESPONDENCE: sagiran@umy.ac.id

DOI:

$10.18196 / \mathrm{mm} .190231$

TYPE OF ARTICLE: Research

\begin{abstract}
The estimates from the experts of the World Health Organization (WHO) indicate that $50 \%$ of the 12 million world population die from coronary heart disease \& blood vessel disease. Low-Density Lipid (LDL) and High-Density Lipid (HDL) ratios are often calculated to estimate the risk of coronary heart disease. Zam-zam water is thought to be efficacious in reducing blood lipid profile levels. This study aims to know the effect of Zam-zam Water on the lipid profile (HDL \& LDL) on a white mouse (Rattus Novergicus). The type of this research is an experimental laboratory design with a pre-post control group conducted for 28 days. The subjects of this study were 25 Rattus norvegicus wistar strains, divided into five groups namely control (aquades) group and four treatment groups (concentrations of $25 \%, 50 \%, 75 \%$ and $100 \%$ ). The data were obtained by measuring the level of LDL and HDL before and after receiving the treatment of Cholesterol Oxidase Para Aminophenazone (CHODPAP). Also, the data were analyzed using ANOVA test and paired t-test. The Anova analysis showed that the administration of Zam-zam water affected the level of HDL and LDL as proven by the significance of differences among study groups $(\mathrm{p}<0.05)$. It is obtained that zam-zam water is $100 \%$ proven to have the most influence on HDL and LDL levels. The analysis of paired T-test showed that there were significant differences before and after treatment $(p<0.05)$. Therefore, it can be concluded that the administration of zamzam water affected the level of HDL and LDL of Rattus norvegicus blood lipid profiles.
\end{abstract}

Keywords: Zam-zam Water; HDL; LDL; Rattus norvegicus

Abstrak: Estimasi para ahli World Health Organization (WHO) menunjukkan bahwa 50\% dari 12 juta penduduk dunia meninggal karena Penyakit Jantung Koroner $\mathfrak{E}$ penyakit Pembuluh Darah. Ratio Low Density Lipid (LDL) dan High Density Lipid (HDL) sering dihitung untuk memperkirakan besarnya risiko Penyakit Jantung Koroner. Air zam-zam diduga berkhasiat menurunkan kadar profil lipid dalam darah. Penelitian ini bertujuan untuk membuktikan pengaruh air zam-zam terhadap profil lipid (HDL $\mathcal{E}$ LDL) pada Rattus novergicus. Jenis penelitian adalah eksperimental laboratorium dengan desain pre-post control group yang dilakukan selama 28 hari. Subjek penelitian adalah 25 ekor Rattus novergicus galur wistar, dibagi menjadi 5 kelompok yaitu kontrol (aquades) dan empat kelompok perlakuan (konsentrasi 25\%, 50\%, 75\% dan 100\%). Data diperoleh dengan cara mengukur kadar LDL dan kadar HDL sebelum dan sesudah perlakuan menggunakan Cholesterol Oxidase Para Aminophenazone (CHODPAP). Data dianalisis menggunakan uji anova dan paired tTest. Analisis Anova menunjukkan bahwa pemberian air Zam-zam berpengaruh pada kadar HDL dan LDL yang dibuktikan dengan adanya signifikansi perbedaan antar kelompok penelitian ( $p<0,05)$. Air Zam-zam 100\% terbukti paling berpengaruh terhadap HDL dan 
LDL. Analisis paired T-test menunjukkan ada perbedaan yang signifikan sebelum dan sesudah perlakuan $(p<0,05)$. Disimpulkan bahwa pemberian air zam-zam berpengaruh pada profil lipid darah HDL dan LDL Rattus norvegicus.

Kata Kunci: Air Zam-zam; HDL; LDL; Rattus novergicus

\section{INTRODUCTION}

Currently, the death rate due to coronary heart disease is still high. World Health Organization (WHO) experts estimate that $50 \%$ of the 12 million world population die due to coronary heart disease \& blood vessel disease. The proportion of deaths from coronary heart disease and blood vessels in Indonesia in 1992-2000 has increased rapidly. ${ }^{1}$

Low-Density Lipid (LDL) and High-Density Lipid (HDL) ratios are often used to calculate the risk of coronary heart disease. When LDL is high (low $\mathrm{HDL}$ ), the risk of suffering from coronary heart disease is also high. LDL is proven to produce the risk of coronary heart disease. ${ }^{2}$ In contrast to LDL levels, high HDL levels will reduce the risk of coronary heart disease. HDL is a powerful predictor of coronary heart disease. Also, it is known that the possibility of the occurrence of coronary heart disease decreases when HDL levels increase. ${ }^{3}$

Nowadays, there are many alternative treatments with Islamic and natural backgrounds to reduce the level of lipid profile in the blood, including zam-zam water. ${ }^{4}$ However, the use of zam-zam water is still rarely used in medicine because of the lack of research on the effect of zam-zam water on health. Most of the research done is about zam-zam water content.

\section{MATERIAL AND METHOD}

This type of research is an experimental laboratory design with a pre-post test control group. The subjects of the study were 25 white male rats (Rattus novergicus) taken by stratified random sampling and observed for four weeks. The maintenance of experimental animals is carried out at the Pharmacology Laboratory enclosure, Faculty of Medicine, Yogyakarta Muhammadiyah University.

The inclusion criteria were wistar strain white rat, male, eight weeks old, bodyweight of 200-300 grams, white coat color. Exclusion criteria were mice that did not want to eat and experienced a decrease in the physical condition during acclimatization.

The independent variable in this study was zam-zam water of various concentrations, while the dependent variable was LDL and HDL levels. The controlled variable was a test animal with the same strain, sex, weight and age, and the same cage and feed.

The materials used in this research were bottled Zam-zam water sold in Muslim stores, BR 2 pellets, fat-rich feed and distilled water. Meanwhile, the equipment were 25 white rat cages, cage mats and lids, drinking and feeding containers, stationery, gloves, scales, 25 ependorfs, microhematocrit pipettes, test tubes, test tube racks, timers, labels and spectrophotometers.

The research was started with a random grouping of test animals into five groups, one control group (distilled water) and four treatment groups. Each group consisted of 5 mice. Acclimatization was carried out for seven days, after which the rats were given high-fat feed for seven days. The preparation of the test material was by diluting Zam-zam water with distilled water so that a predetermined concentration was obtained namely $25 \%$, $50 \%, 75 \%$, and $100 \%$. Next was the treatment stage, namely the administration of Zam-zam water as a substitute for drinking water with various concentrations for 28 days.

Data was collected by measuring LDL and HDL levels of white rat blood before and after treatment. The measurement was conducted by using Cholesterol Oxidase Para Aminophenazone (CHODP$\mathrm{AP}$ ) recommended by the European Atherosclerosis Society. ${ }^{5}$

Data analysis was performed with a set of computers using the one-way ANOVA test method continued Post Hoc test, namely the Tukey Test to know the difference of the effect of the treatments. Paired T-test used to compare results before and after treatment.

\section{RESULT}

The observations made by recording HDL and LDL levels before and after treatment in the form of average HDL and LDL levels before and after treatment can be seen in Figure 1 and Figure 2.

Table 1. shows that there is a change of HDL and LDL level before and after the treatment, which is indicated by the difference between HDL and LDL level. From Table 1. it can be seen that the most significant difference is found in the treatment with $100 \%$ Zam-zam water, and the smallest change is seen in the treatment with distilled water.

Table 1. showed a significant difference on the effect between the control group (distilled water) and the four Zam-zam Water groups at HDL and LDL levels before and after treatment. 


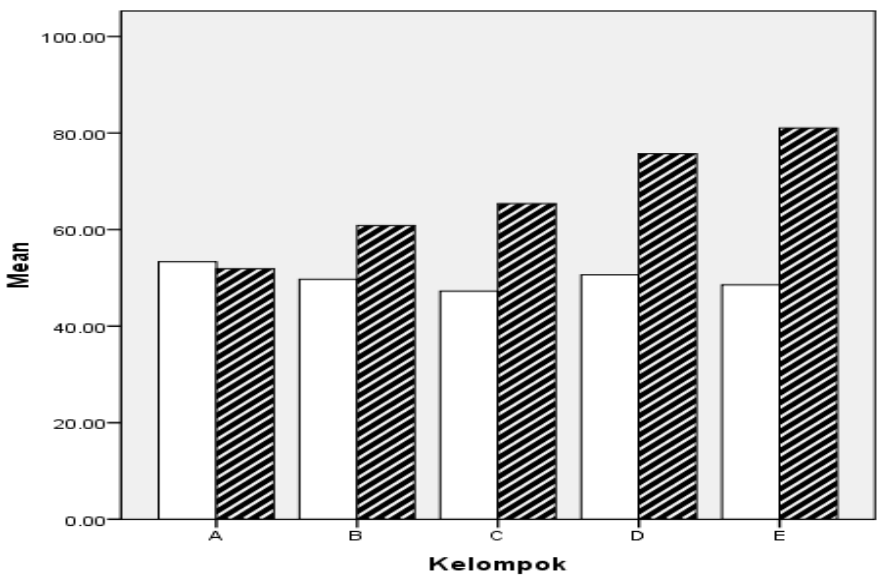

员HDL sebelum

Kelompok

Figure 1. Average Level of HDL (mg/dl), Description: A: distilled water; B: Zam-zam water 25\%; C: Zamzam water 50\%; D: Zam-zam water 75\%; E: Zam-zam water 100\%

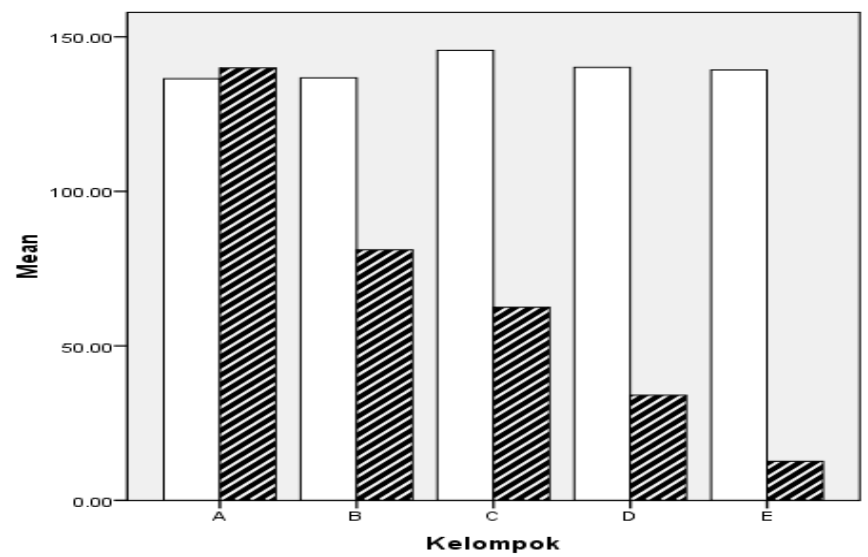

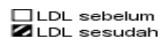

Figure 2. Average Level of LDL (mg/dl), Description: A. distilled water; B. Zam-zam water 25\%; C. Zamzam water 50\%; D. Zam-zam water 75\%; dan E. Zam-zam water 100\%

Table 1. Average Difference in Levels HDL and LDL (mg/dl)

\begin{tabular}{|c|c|c|c|c|c|c|}
\hline \multirow{2}{*}{ Description } & \multirow{2}{*}{ Significance } & \multicolumn{5}{|c|}{ Group } \\
\hline & & $\mathrm{A}$ & $\mathrm{B}$ & $\mathrm{C}$ & $\mathrm{D}$ & E \\
\hline $\begin{array}{c}\text { Average } \\
\text { differences HDL }\end{array}$ & 0,001 & $-1,42 \pm 0,54^{\mathrm{a}}$ & $11,13 \pm 2,21^{b}$ & $18,12 \pm 5,16^{c}$ & $25,11 \pm 3,28^{d}$ & $32,49 \pm 7,58^{\mathrm{e}}$ \\
\hline $\begin{array}{l}\text { Average LDL } \\
\text { difference }\end{array}$ & 0,000 & $3,48 \pm 0,58^{\mathrm{a}}$ & $-55,67 \pm 2,96^{\mathrm{b}}$ & $-83,14 \pm 8,25^{c}$ & $\cdot 106,11 \pm 6,10^{d}$ & $-126,65 \pm 3,70^{e}$ \\
\hline
\end{tabular}

Description : A. distilled water; B. Zam-zam water 25\%; C: Zam-zam water 50\%; D:Zam-zam water75\%; E:

Zam-zam water $100 \%$

Table 2. A Paired T-Test of the Average of HDL Level (mg/dl) and the Average of the Difference of HDL Level Before and After the Treatment

\begin{tabular}{|c|c|c|c|c|c|}
\hline \multirow[b]{2}{*}{ Group } & \multicolumn{2}{|c|}{ HDL level $(\mathrm{mg} / \mathrm{dl})$} & \multirow[b]{2}{*}{$\mathrm{p}$-Value } & \multicolumn{2}{|c|}{ CI 95\% } \\
\hline & $\begin{array}{c}\text { Average of } \\
\pm \text { beginningSD }\end{array}$ & $\begin{array}{l}\text { Average of } \\
\pm \text { final SD }\end{array}$ & & $\begin{array}{l}\text { Lower } \\
\text { Limit }\end{array}$ & $\begin{array}{l}\text { Upper } \\
\text { Limit }\end{array}$ \\
\hline Distilled water & $53,33 \pm 1,74$ & $51,91 \pm 1,67$ & 0,004 & 0,75 & 2,09 \\
\hline Zam-zam water $25 \%$ & $49,70 \pm 2,26$ & $60,84 \pm 1,02$ & 0,000 & $-13,88$ & $-8,38$ \\
\hline Zam-zam water $50 \%$ & $47,24 \pm 4,73$ & $65,37 \pm 1,02$ & 0,001 & $-24,53$ & $-11,71$ \\
\hline Zam-zam water $75 \%$ & $50,61 \pm 2,90$ & $75,72 \pm 1,02$ & 0,000 & $-29,19$ & $-21,03$ \\
\hline Zam-zam water $100 \%$ & $48,54 \pm 6,63$ & $81,03 \pm 2,01$ & 0,001 & $-41,90$ & $-23,07$ \\
\hline
\end{tabular}

Description: a negative sign in the average column of the difference percentage indicates an increase in HDL levels and vice versa. 
Table 3. A Paired T-Test of the Average of LDL Level (mg/dl) and Percentage of the Difference of LDL Level Before and After the Treatment

\begin{tabular}{ccccrrr}
\hline \multirow{2}{*}{ Group } & \multicolumn{2}{c}{ LDL level serum $(\mathrm{mg} / \mathrm{dl})$} & & \multicolumn{2}{c}{ CI 95\% } \\
\cline { 2 - 3 } \cline { 5 - 6 } & $\begin{array}{c}\text { Average of } \pm \\
\text { beginningSD }\end{array}$ & Average of \pm final SD & Significance & $\begin{array}{c}\text { Lower } \\
\text { Limit }\end{array}$ & $\begin{array}{c}\text { Upper } \\
\text { Limit }\end{array}$ \\
\hline Distilled water & $136,45 \pm 6,16$ & $139,94 \pm 5,74$ & 0,000 & $-4,21$ & $-2,75$ \\
Zam-zam water 25\% & $136,71 \pm 5,01$ & $81,04 \pm 2,78$ & 0,000 & 51,99 & 59,34 \\
Zam-zam water 50\% & $145,63 \pm 6,51$ & $62,49 \pm 2,98$ & & 0,000 & 72,89 & 93,39 \\
Zam-zam water 75\% & $140,14 \pm 5,81$ & $34,02 \pm 1,90$ & & 0,000 & 98,53 & 113,69 \\
Zam-zam water 100\% & $139,30 \pm 4,36$ & $12,64 \pm 2,04$ & & 0,000 & 122,06 & 131,25 \\
\hline
\end{tabular}

Description: a negative sign in the average column of the difference percentage indicates an increase in LDL levels and vice versa.

\section{DISCUSSION}

Table 1. showed a significant difference on the effect between the control group (distilled water) and the four Zam-zam Water groups at HDL and LDL levels before and after treatment. This difference is caused by the high levels of minerals contained in Zam-zam water such as Sodium, Calcium, Magnesium, Potassium, $\mathrm{HCO}_{3}$, Chloride, Fluoride, $\mathrm{NO}_{3}$, and $\mathrm{SO}_{4}$.

Associated with calcium content, the results of this study are not in line with previous studies which stated that the administration of a calcium diet does not increase HDL levels and does not reduce LDL levels. ${ }^{6}$ Also, there are studies said a high calcium diet does not show statistically significant results in lowering cholesterol. ${ }^{7}$ The effect of zamzam water on HDL and LDL may be more due to the content that is not only high in calcium but also has other substances such as Sodium, Magnesium, Potassium, $\mathrm{HCO}_{3}$, Chloride, Fluoride, $\mathrm{NO}_{3}, \mathrm{SO}_{4} .^{8}$

According to Rosanof and Seelig (2004), ${ }^{9}$ magnesium can increase HDL and decrease LDL. Related to the results of this study, the possible influence of zam-zam water on HDL and LDL levels is due to its magnesium content. The mechanism of magnesium in increasing HDL levels and reducing LDL levels is by activating the enzyme of lecithin cholesterolacyl transferase (LCAT). ${ }^{10}$

\section{CONCLUSION}

The administration of Zam-zam water for 28 days can increase HDL levels and reduce LDL levels.

\section{REFERENCE}

1. Gobel FA, \& Mahkota R (2006). Faktor-Faktor Yang Mempengaruhi Kematian Pasien Penyakit Jantung Koroner Di Pusat Jantung Nasiopnal Harapan Kita Tahun 2004.KERMAS Jurnal Kesehatan Masyarakat Nasional Fakultas
Kesehatan Masyarakat Universitas Indonesia1.

2. Yatim, F. (2002). Waspadai Jantung Koroner Stroke Meninggal Mendadak Atasi Dengan Pola Hidup Sehat. Jakarta : Pustaka Populer Obor

3. Karniawati, M., \& Wijaya, A. (2005). Kualitas HDL-C (bukan kuantitas) Menentukan Tingkat Proteksi Terhadap Aterosklerosis. Forum Diagnosticum Prodia Diagnostic Educational Service.

4. Handoyo, I. L. (2007). Manfaat Air Zam-zam. Diakses tanggal 05 april 2009, dari http://menapaksehat.blogspot.com/2007/11/ma nfaat-air-zam-zam.html

5. Kotiah, Umi.(2007). Pengaruh Pemberian Ekstrak Lidah Buaya Terhadap Kadar Kolesterol Hdl Dan Ldl Serum Tikus Putih Hiperkolesterolemi. Skripsi strata satu, Universitas Negeri Semarang, Semarang.

6. Zemel, .B.M. (2002). Regulation Of Adiposity And Obesity Risk By Dietary Calcium: Mechanisms And Implications. Diakses tanggal 26 April 2006, dari www.ncbi.nlm.nih.gov/pubmed/11999543

7. Bostick, Roberd M. MD, MPH, Fosdick, Lisa MS, Grandits, Greg A. MS, Grambsch, Patricia PhD, Gross, Myron PhD, Louis, Thomas A. PhD.(2000). Effect of Calcium Supplementation on Serum Cholesterol and Blood Pressure. Volume 9. diakses 24 April 2009, dari http://www.archfammed.com.

8. Zuhair, N.A \& Khounganian, N. (tanpa tahun).A Comparative Study Between The Chemical Composition Of Potable Water And Zamzam Water In Saudi Arabia. Dari docs.ksu.edu.sa/PDF/Articles43/Article430961.pdf

9. Rosanoff A, Seelig MS. Comparison of mechanism and functional effects of magnesium and statin pharmaceuticals. J Am Coll Nutr. 2004 Oct;23(5):501S-505S.

10. Ansari MR, Maheshwari N, Shaikh MA, Laghari MS, Darshana, Lal K, Ahmed K. Correlation of serum magnesium with dyslipidemia in patients on maintenance hemodialysis. Saudi J Kidney Dis Transpl 2012;23: 